\title{
COMPETITIVE PRESSURE AND TECHNOLOGICAL DEGREE OF THE PRODUCT PORTFOLIO: IMPLICATIONS FOR FIRM PERFORMANCE*
}

\author{
Szabolcs Szilárd SEBREK - Betsabé Pérez GARRIDO
}

(Received: 6 June 2014; revision received: 9 September 2014; accepted: 17 September 2014)

\begin{abstract}
This paper seeks to illuminate empirically a class of drivers of firm performance hitherto neglected in the economic literature. To accomplish this objective, we distinguished three elements: sales volume, participation in technology alliancing, and successful patent issuing. Our findings suggest that competitive pressure posed by larger rivals in an industry affects sales performance negatively, but the possession of absorptive capacity can counter this deleterious effect. Findings regarding the effects caused by a product portfolio with high technological content are mixed. Depending on the performance measure applied, the results show evidence of adverse outcomes for sales, U-shaped effects for participation in technology alliancing and inverted U-shaped results for patenting. We obtained our raw data from the 2006 and 2008 PITEC database, which is the Spanish equivalent of the EU Community Innovation Survey. Our sample embraces more than 3000 firms.
\end{abstract}

Keywords: competitive pressure, absorptive capacity, technological degree of the product portfolio, firm performance, large sample size

JEL classification indices: L25, M10, M19

* The authors thank P. Mendi, A. Barge-Gil, Z. Kovács, L. Szabó, Á. Török, and seminar participants at University of Pannonia (Veszprém, Hungary), Universidad de Navarra (Pamplona, Spain) and 2014 Redete Conference at University of Banja Luka (Bosnia and Herzegovina) for comments and suggestions on an earlier draft. Financial support from the Spanish Ministry of Education and Science (Grant No. ECO2009-08308), and the European Union (Grant No. TÁMOP-4.2.3-12/1/KONV-2012-0026) is gratefully acknowledged. The usual disclaimer applies.

Betsabé Pérez Garrido, Assistant Professor at the Faculty of Business and Economics, Department of Quantitative Methods, University of Pannonia. E-mail: betsabe@gtk.uni-pannon.hu

Szabolcs Szilárd Sebrek, corresponding author. Assistant Professor at the Faculty of Business and Economics, Department of Management, University of Pannonia.

E-mail: sebrek@gtk.uni-pannon.hu 


\section{INTRODUCTION}

A relevant body of research tries to identify the factors that can enhance or impede the performance of firms. Prior publications revealed that mostly absolute firm size, complementary assets, location, external channels of R\&D, and breadth of product range were at the forefront of empirical investigations (Sorenson 2000; Dobrev et al. 2002; Folta et al. 2006; Laursen - Salter 2006; Giarratana - Fosfuri 2007). These results notwithstanding, there might be other potential issues at work, which the business press and anecdotal evidences point out, for example, scale economies, the innovativeness of the product portfolio, and the possession of absorptive capacity (Dobrev - Carroll 2003; Giarratana, 2004; Chiaroni et al.; The Economist 2011a). What, then, are the further drivers of firm performance? In order to address our research question, we draw on a population of 3048 firms taken from the Spanish Technological Innovation Panel (PITEC) database, which is a national equivalent of the Community Innovation Survey (CIS). CIStype surveys address detailed questions on firms' innovative activities directly to managers, and have also been employed, among others, in Belgium, the United Kingdom, and Switzerland.

This study's central contribution to the economic literature in firm performance relies on connecting it with the rate of product portfolio innovativeness. In so doing, we also explore potential non-linearities that might better depict this link. Sparked by the insight of Dobrev - Carroll (2003), our research also adds to the literature on competitive pressure by (1) taking into consideration the effect of the relative size of participants within the respective industry on performance, and by (2) investigating whether and how such an effect is being moderated by the absorptive capacity (Cohen - Levinthal 1989; Zahra - George 2002) of the focal organisation.

This paper consists of several additional sections in which we review theory related to key concepts and develop hypotheses (Section 2). We then describe our data, all the variables employed in the empirical analyses and the methodologies we applied (Section 3). In Section 4, we present and discuss the results, and lastly, we summarise conclusions and delineate some directions for future research (Section 5).

\section{THEORY AND HYPOTHESES}

In this article, we go inside the firm primarily to examine the effects of size, absorptive capacity, and product portfolio characteristics for firm performance. Scale and product line are organisational attributes of great significance high- 
lighted by the seminal works of Schmalensee (1978) and Henderson - Cockburn (1996). Via a historical and detailed case study of the U.S. flat-glass industry, Anderson - Tushman (1990) depict the evolution of the technological progress of machines in capacity as measured by square feet per hour of sheet glass. They reveal that such advances set the performance frontier of the industry and affect conditions of scale economies, which eventually shape firm competitiveness. We adhere to the view that absorptive capacity turns out to be a substantial factor that influences the scale pressure potentially imposed on firms by their rivals, as it fosters organisational learning, innovation, and the capturing of external knowledge flows, extant in the firms' outer environment (Cohen - Levinthal 1990; Escribano et al. 2009).

Along with scale, another important firm characteristic is associated with choices of product creation strategy (Sorenson 2000). Here, an important choice variable for the management of the firm can be the level of the technological content of the product portfolio, as pointed out, among others, by Garud - Kumaraswamy (1993) and Giarratana - Fosfuri (2007).

\subsection{Competitive pressure}

Scale economies exert a determinative force in several industries on organisational evolution, such as the automobile industry in the U.S. and in Europe (Dobrev - Carroll 2003), the U.S. television receiver industry (Klepper Simmons 2000; The Economist 2011a), the beer-brewing industry (Carroll Swaminathan 2000), the worldwide container shipping industry (The Economist 2011b), and the smartphone industry (The Economist 2011a). The aftermath of scale-competition is the lessened position of smaller organisations against their larger rivals, which leads to higher average costs, causing internal inefficiency. Compared to large competitors, this is manifested in supplier and buyer markets, worsened competitiveness on the labour market due to unfavourable wage conditions, and a lack of overall job security for employees (Dobrev et al. 2002; Dobrev - Carroll 2003; The Economist 2011a, b). Another source of scale-based selection pressure imposed on smaller entities is associated with preferential treatment enjoyed by large firms from regulatory bodies and politicians, which gives them an advantage in intrapopulation competition (Nelson - Winter 1982). Furthermore, not only economies of scale, but also scope economies can be linked to larger relative size resulting from encompassing different but complementary activities within their organisational boundaries (Henderson - Cockburn 1996). For instance, large firms from the information and communication technology sector such as Phillips and Samsung realise benefits from 
the so-called brand halo effects through competing in related technological subfields (The Economist 2011a).

Dobrev - Carroll (2003) provide a detailed discussion regarding the theoretical and analytical relevance of dividing organisational size into two types. In line with this article, we distinguish between absolute and relative size, as this latter represents noteworthy economic advantages via lower costs, political and institutional advantages, and important complementarities originating from scale-competition. In addition, studying the U.S. television receiver industry, Klepper - Simmons (2000) observed that major product and process innovations were mainly produced by large incumbent organisations. Because economies of scale act as a major driver of competition in the sectors referred to above, we believe that it must also affect firm performance. We posit that scale competition negatively affects smaller competitors because of reduced competitiveness due to scale pressure imposed by larger rivals.

Hypothesis 1: Higher rates of competitive pressure imposed on firms by bigger rivals deteriorate firm performance.

\subsection{Moderating role of absorptive capacity}

Absorptive capacity is an important element to boost firms' ability toward learning and innovation (Cohen - Levinthal 1990). The literature discusses two key roles played by absorptive capacity regarding external knowledge (Cohen - Levinthal 1989; Zahra - George 2002). According to the first role, absorptive capacity is conducive for firms to detect available external knowledge flows (Escribano et al. 2009). The second is associated with the benefits the firm obtains when using or exploiting external knowledge. The former trait is called potential, while the latter realised absorptive capacity.

According to Fabrizio (2009), there is a strong link between a firm's absorptive capacity building techniques and the search process for innovation, placing the firm in an advantageous situation in terms of both the timing and quality of search outcomes. These advantages can translate into marketable products that eventually contribute to increased sales volumes, which offset deleterious effects of scale-based pressure and promote firm performance. Absorptive capacity is further buttressed because it breeds the speed and frequency of incremental innovation, which rely heavily on the existing knowledge base of firms (Anderson - Tushman 1990; Kim - Kogut 1996; Helfat 1997). Van den Bosch et al. (1999) point out that in turbulent and unstable periods, firms are likely to increase their absorptive capacity level and the focus of firms' knowledge absorption will be 
on exploration. Smaller rivals within an industry can experience a similar context in which larger rivals make the environment more volatile due to their market power. Samsung, as an example, using its market power introduces a great deal of instability for smaller or weaker rivals in the worldwide smartphone industry (The Economist 2011a). If smaller rivals manage to boost their absorptive capacity, then they can develop combinative capabilities that benefit high scope and flexibility of knowledge absorption processes. The evolution of combinative capabilities is beneficial for firms' aspiration level and expectation formation that result in a more proactive posture towards emerging business opportunities (van den Bosch et al. 1999).

Therefore, we can assume that there is heterogeneity among firms in the level of absorptive capacity. Firms with higher levels of absorptive capacity are able to identify more external knowledge and can exploit it more efficiently (Escribano et al. 2009). These abilities attributed to higher degrees of absorptive capacity are the ones smaller firms can utilise when facing competitive pressure vis-à-vis larger rivals.

Hypothesis 2: Strong absorptive capacity is a countervailing factor to the negative effect of high competitive pressure and thus enhances firm performance.

\subsection{Technological content of the product portfolio}

The management of the product portfolio represents a key strategic issue for firms (Sorenson 2000; Giarratana - Fosfuri 2007; Eggers 2012). According to prior literature, product scope width is particularly conducive during higher degrees of environmental turbulence (Dobrev et al. 2002) and for pursuing a hedging strategy against risk of losses (Sorenson 2000). Deeper product broadening is suitable to raise entry barriers (Lancaster 1990) and obtain demand synergies via a “one-stop shopping” product offer (Giarratana - Fosfuri 2007).

In competitive industries, rivalry faced by firms is associated with poorer performance and activates internal organisational learning processes (Barnett - Sorenson 2002). Such internal learning processes can entail that firms commit resources to continuously refine their product offerings that meet more closely the needs and expectations of their customers. Industry wisdom suggests that firms do complement their internal channels and often prefer to be exposed to outside ideas (Sakkab 2002; Chiaroni et al. 2011).

As found by Ansoff - Stewart (1967), the breadth of product-market focus and the firm's technology base are interlaced. We define the technological degree of the product portfolio as consisting of products that display a high level of innova- 
tiveness. We argue that firms having developed a product portfolio of extremely innovative products have worse company performance. First, having a portfolio of products with excessive innovativeness could produce a product cannibalisation effect (Garud - Kumaraswamy 1993) inside existing product categories when the firm updates its product offerings too often. Second, the excessive innovativeness of products could entail the rise of control and coordination costs (Jones - Hill 1988). Third, moderate dependence on extramural knowledge can contribute to the improvement of product features (Giarratana 2004). However, extensive reliance can hinder performance (Laursen - Salter 2006) and greatly confine the developer organisation's ability to regulate the product's technological trajectory (including the features of the product) by losing some control compared to closed design (Almirall - Casadeus-Masanell 2010). In sum, the hypothesis can be stated as:

Hypothesis 3: Firms with a product portfolio that exhibits a higher level of technological content display lower company performance.

\section{EMPIRICAL ANALYSIS}

\subsection{Data}

We turned to the Panel de Innovación Tecnológica (PITEC) database to test our ideas. The dataset is drawn from the Community Innovation Survey gathered in Spain, in 2006 and 2008, and administered by the Spanish National Statistics Institute. Numerous previous works resorted to this database (e.g. Escribano et al. 2009; Barge-Gil 2010) or its U.K. counterpart (Laursen - Salter 2006). Due to sample selection restrictions we included only those firms in the sample that realised R\&D activities, expending a positive amount of resources on innovation activities. In the end, our sample embraces 3048 firms.

\subsection{Dependent variables}

Following the literature (Baum - Silverman 2004; Folta et al. 2006; Santamaría et al. 2009), we examine firm performance using multiple measures that embrace a range of dimensions critical to success: the logarithm of sales (LOG_SALES, Model 1), success in attracting technology alliance partners (TECHN_ALLIANCING, Model 2), and development of intellectual property by issuing patents (PATENTING, Model 3). For these two latter dependent variables (for Model 2 and 3), we created dichotomous, $0-1$ variables to depict the underlying phe- 
nomenon (obtaining a patent and crafting a technology alliance). These metrics represent a comprehensive range of measures as they not only involve a global performance measure (volume of sales), but also open up the possibility for semi-external (technology networking) and purely internal (patents) performance specifications.

\subsection{Variables of theoretical interest}

The variable CPRESSURE aims to grasp competitive pressure. Following Dobrev - Carroll (2003), it is operationalised by the following formula:

$$
C P_{i t}=\sum_{s_{j t}>s_{i t}}\left[\left(S_{i t}-S_{\min }\right)^{-1 / 4}-\left(S_{j t}-S_{\min }\right)^{-1 / 4}\right],
$$

where $S_{i t}$ stands for the sales volume of firm $i$. The variable measures the aggregate distance of firm $i$ from all larger firms $j$ inside its respective industry, applying an adjustment with the smallest firm. As the formula shows, the greater the number of larger rivals, the greater the competitive pressure the focal firm faces. In our specifications, we interact the CPRESSURE variable with absorptive capacity, as implied by the second hypothesis. The construct absorptive capacity (ABS_CAPAB) is grasped through the principal component of four variables such as internal $R \& D$, permanent $R \& D$, training, and $R \& D$ skills. This latter encompasses the number of scientists and researchers over total employees. Internal $R \& D$ captures the amount of internal $R \& D$ expenditures measured on a log scale, while permanent $R \& D$ represents a dummy taking on the value 1 in the case of the firm having a fully staffed $R \& D$ department. The variable training corresponds to a dummy variable showing whether any training activity for the firm's R\&D personnel has been provided. The construction of ABS_CAPAB is in line with Escribano et al. (2009).

The technological degree of the product portfolio (TECH_PP) is measured as the fraction of the firm's turnover associated with both products new to the world market and products new to the firm. Thus, TECH_PP simultaneously incorporates a firm's product offerings and their rate of technological content. Next to linearity (Giarratana - Fosfuri 2007), former studies depict a potential nonlinear relation between product proliferation strategies and firm performance (Barroso - Giarratana 2013). In order to capture any curvilinear nature of the relationship between firm performance and technological degree of the product portfolio, we introduce the square term of TECH_PP into our model specifications, if significant nonlinearity can be demonstrated. 


\subsection{Control variables}

We introduce a series of control variables to distinguish effects different from our variables of theoretical interest. Firms' learning and innovation potential measured by the absorptive capacity (ABS_CAPAB) variable was already demonstrated above. Similarly to Laursen - Salter (2006), we control for the size of the actual product market (GEO_MARK). GEO_MARK takes values from 1 to 4, with 1 corresponding to "local", 2 to "regional", 3 to "national", and 4 to "international". Firm success through the higher commercialisation potential of products crucially depends on downstream assets (Teece 1986; Gans - Stern 2003). To be aligned with these important observations, we follow Arbussá - Coenders (2007) and construct the variable investment in downstream activities (INVESTMENT_DA), which is a dichotomous variable, displaying 1 if the organisation in question invested in either design and other technical procedures or in internal or external marketing activities. The performance of firms might be affected by the degree of environmental uncertainty. To isolate such effects, we introduce the variable TURBULENCE

\section{Table 1}

Definition of the variables

\begin{tabular}{|c|c|}
\hline Variable name & Definition \\
\hline LOG_SALES & The logarithm of 2008 total annual sales. \\
\hline TECHN_ALLIANCING & $\begin{array}{l}\text { A dummy that equals } 1 \text { if the firm has undertaken a strategic technol- } \\
\text { ogy alliance during the period 2006-2008, and } 0 \text { otherwise. }\end{array}$ \\
\hline PATENTING & $\begin{array}{l}\text { A dummy that equals } 1 \text { if the firm has issued a patent during the pe- } \\
\text { riod 2006-2008, and } 0 \text { otherwise. }\end{array}$ \\
\hline CPRESSURE & $\begin{array}{l}\text { The aggregate distance of firm } i \text { from all larger firms } j \text { inside its re- } \\
\text { spective industry based on the volume of sales in } 2006 \text {. }\end{array}$ \\
\hline TECH_PP & $\begin{array}{l}\text { The total fraction of the firm's turnover associated with both products } \\
\text { new to the world market and products new to the firm in } 2006 \text {. }\end{array}$ \\
\hline ABS_CAPAB & $\begin{array}{l}\text { The principal component of four variables all from 2006: (a) internal } \\
R \& D \text {, (b) permanent } R \& D \text {, (c) training and (d) R\&D skills. }\end{array}$ \\
\hline GEO_MARK & $\begin{array}{l}\text { A categorical variable from } 2006 \text { where } 1 \text { corresponds to local, } 2 \text { to } \\
\text { regional, } 3 \text { to national, and } 4 \text { to international. }\end{array}$ \\
\hline INVESTMENT_DA & $\begin{array}{l}\text { A dummy that is equal to } 1 \text { if the firm has invested in both design } \\
\text { and other technical procedures or in internal or external marketing } \\
\text { activities in } 2006 \text {. }\end{array}$ \\
\hline TURBULENCE & $\begin{array}{l}\text { The disparity between the industry rate of increase in sales of new or } \\
\text { significantly improved products and the average rate of increase for } \\
\text { the whole economy (including all industries) in } 2006 \text {. }\end{array}$ \\
\hline IND_PARK & $\begin{array}{l}\text { A dummy that takes up the value } 1 \text { if the firm is situated in a scientific } \\
\text { or technological park, and } 0 \text { otherwise. }\end{array}$ \\
\hline ABS_SIZE & The number of employees on a log scale in 2006. \\
\hline
\end{tabular}


that refers to the turbulent nature of an industry. The variable is calculated as the difference between the industry rate of increase in sales of new or significantly improved products and the average rate of increase for the whole economy (including all industries). Firm location in industrial parks can entail access to cluster benefits (Folta et al. 2006) and to intermediary services (Lee et al. 2010). Therefore, building on the specific survey question, we include the dummy variable IND_PARK in our specifications; it takes up the value 1 if the firm is situated in a scientific or technological park. We use the number of employees on a log scale as a measure of firm's (absolute) size (ABS_SIZE), which illuminates its effect from relative size considerations. A succinct summary of the definitions of all variables employed is shown in Table 1, while Table 2 displays the basic statistics for the variables used for our analyses, and Table 3 provides covariates correlations.

Table 2

Descriptive statistics

\begin{tabular}{llrrrr}
\hline & Variable name & Mean & \multicolumn{1}{c}{ SD } & \multicolumn{1}{c}{ Min } & \multicolumn{1}{c}{ Max } \\
\hline 1 & CPRESSURE & 0.98 & 1.80 & 0.00 & 31.55 \\
2 & TECH_PP & 34.58 & 36.91 & 0.00 & 100.00 \\
3 & ABS_CAPAB & 0.00 & 1.09 & -12.12 & 1.59 \\
4 & GEO_MARK & 3.55 & 0.77 & 1.00 & 4.00 \\
5 & INVESTMENT_DA & 0.34 & 0.48 & 0.00 & 1.00 \\
6 & TURBULENCE & 0.31 & 3.40 & -20.03 & 11.29 \\
7 & IND_PARK & 0.03 & 0.17 & 0.00 & 1.00 \\
8 & ABS_SIZE & 4.31 & 1.32 & 0.69 & 9.23 \\
\hline
\end{tabular}

Table 3

Covariates correlations

\begin{tabular}{rrrrrrrrr}
\hline & \multicolumn{1}{c}{1} & \multicolumn{1}{c}{2} & \multicolumn{1}{c}{3} & 4 & 5 & 6 & 7 & 8 \\
\hline 1 & 1.00 & & & & & & & \\
2 & 0.06 & 1.00 & & & & & & \\
3 & 0.09 & -0.01 & 1.00 & & & & & \\
4 & -0.22 & 0.02 & -0.11 & 1.00 & & & & \\
5 & -0.01 & 0.09 & -0.21 & 0.05 & 1.00 & & & \\
6 & 0.00 & 0.11 & 0.09 & 0.01 & 0.03 & 1.00 & & \\
7 & -0.01 & 0.03 & -0.07 & 0.03 & 0.01 & -0.05 & 1.00 & \\
8 & -0.54 & -0.11 & -0.24 & 0.25 & 0.05 & -0.03 & -0.02 & 1.00 \\
\hline
\end{tabular}




\subsection{Methodology}

Three models will be used to verify the proposed hypotheses. Model 1 considers the logarithm of sales (LOG_SALES) as the dependent variable; given its continuous nature, we apply the multiple linear regression model. The response variables in Models 2 and 3 are TECHN_ALLIANCIG and PATENTING, respectively. In both cases it is a binary variable, meaning that it follows a Bernoulli distribution, i.e. $y_{i} \sim$ Bernoulli $\left[\pi\left(\mathbf{x}_{i}\right)\right]$. An appropriate model for this type of response variable is the logistic regression model (Green 2008), which can be expressed in the following way:

$$
\ln \left[\frac{\pi\left(\mathbf{x}_{i}\right)}{1-\pi\left(\mathbf{x}_{i}\right)}\right]=\beta_{0}+\beta_{1} x_{i 1}+\cdots+\beta_{p} x_{i p}+u_{i} .
$$

The logistic regression model uses a transformation of the probabilities $\pi\left(\mathbf{x}_{i}\right)$ to ensure that the estimated probabilities remain between the range of 0 and 1 . Under this model, the probability of pertaining to one of the two categories is given by:

$$
\pi\left(\mathbf{x}_{i}\right)=\frac{1}{1+e^{-\left(\beta_{0}+\sum_{j=1}^{p} \beta_{j} x_{i j}\right)}}=\frac{e^{\left(\beta_{0}+\sum_{j=1}^{p} \beta_{j} x_{i j}\right)}}{1+e^{\left(\beta_{0}+\sum_{j=1}^{p} \beta_{j} x_{i j}\right)}} .
$$

The estimation can be based on the maximum likelihood procedure where the log-likelihood function takes the next form:

$\operatorname{In} L(\boldsymbol{\beta})=\sum_{i=1}^{n}\left\langle y_{i} \cdot \ln \left[\frac{e^{\left(\beta_{0}+\sum_{j=1}^{p} \beta_{j} x_{i j}\right)}}{1+e^{\left(\beta_{0}+\sum_{j=1}^{p} \beta_{j} x_{i j}\right)}}\right]+\left(1-y_{i}\right) \cdot \ln \left[1-\frac{e^{\left(\beta_{0}+\sum_{j=1}^{p} \beta_{j} x_{i j}\right)}}{1+e^{\left(\beta_{0}+\sum_{j=1}^{p} \beta_{j} x_{i j}\right)}}\right]\right\rangle$.

The estimation of Models 2 and 3 can be accomplished with the statistical software R through the function $\mathrm{glm}$. We include in Models 2 and 3 the Goodman-Kruskal's lambda and the Hosmer-Lemeshow test as measures for statistical validity of these models. The former varies between 0 and 1 , and provides the probability of decrease in error in predicting the dependent variable given the information contained in all the independent variables (Goodman - Kruskal 1954). The idea behind the latter is to group observations into (generally ten) categories on the basis of their predicted probabilities. Then a Pearson chi-squared statistic is calculated. Based on this statistic, a $p$-value is obtained at which, being greater 
than 0.05, one can argue that the model achieved an appropriate goodness of fit (Hosmer - Lemeshow 1989; Dobson 2002).

To alleviate any potential endogeneity problems caused by simultaneity between firm performance and the hypothesised drivers captured through our core variables, we introduce a time lag; this procedure aligns with prior studies (Arbussá - Coenders 2007; Escribano et al. 2009). Accordingly, the dependent variables (sales volume, participation in technology alliancing and patent issuing) in the estimations are drawn from the 2008 PITEC survey, and all explanatory variables originate from the 2006 survey.

\section{RESULTS AND DISCUSSION}

Tables 4, 5 and 6 provide the estimation results incorporating Models 1, 2 and 3 , respectively. Our first hypothesis gains support only in Model 1, where the variable CPRESSURE is negative and statistically significant. When experiencing higher degrees of competitive pressure within the respective industry, the

Table 4

Results of Model 1

\begin{tabular}{lccc}
\hline $\begin{array}{l}\text { Method } \\
\text { Dependent variable }\end{array}$ & \multicolumn{3}{c}{ Multiple Linear Regression } \\
& \multicolumn{3}{c}{ Model 1 } \\
& Coefficient & Std error & \\
Constant & 11.47 & 0.08 & $* * *$ \\
Core variables & & & \\
CPRESSURE & -0.14 & 0.01 & $* * *$ \\
CPRESSURE X ABS_CAPAB & 0.02 & 0.01 & $*$ \\
TECH_PP & -0.001 & 0.0003 & $*$ \\
TECH_PP2 & - & - & \\
Control variables & & & $* * *$ \\
ABS_CAPAB & -0.07 & 0.01 & $* * *$ \\
GEO_MARK & 0.13 & 0.02 & $*$ \\
INVESTMENT_DA & -0.06 & 0.03 & \\
TURBULENCE & -0.004 & 0.004 & + \\
IND_PARK & -0.14 & 0.08 & $* * *$ \\
ABS_SIZE & 1.07 & 0.01 & $* * *$ \\
Adjusted R-square & 0.84 & & \\
p-value & & $<2.2 \mathrm{e}-16$ & \\
\hline
\end{tabular}

Note: $* * * p$-value $<0.001, * * p$-value $<0.01, * p$-value $<0.05$, $\dagger p$-value $<0.1$. 
performance of firms captured by the volume of sales deteriorates, as implied by Hypothesis 1. It is an interesting finding per se that other key strategic performance dimensions do not suffer from deleterious hindrance associated with small size. Therefore, smaller firms can have equal probabilities to act seamlessly at initiating strategic technology alliances, and to increase their involvement in patent granting. Through the joint inclusion of CPRESSURE and ABS_SIZE, we could parse out effects associated with economies of scale and scope, providing a value addition to prior literature.

Hypothesis 2 is captured through creating an interaction variable between competitive pressure and absorptive capacity (CPRESSURE X ABS_CAPAB), and it is reinforced by Model 1 . The finding revealed in Model 1 argues that smaller firms with a strong absorptive capacity offset the impediment linked to small size and increase firm sales. In contrast, the largest firms that display zero on competitive pressure grasp no benefit toward achieving higher sales levels from building up a strong absorptive capacity as their interaction becomes zero as well. Figure 1 graphically shows these results.

As pointed out by several models, the technological degree of the product portfolio is a key determinant of firm performance. According to our indication, we experimented with the inclusion of the square term of TECH_PP to discern whether a linear or curvilinear relationship is the most appropriate. Model 1 deliv-

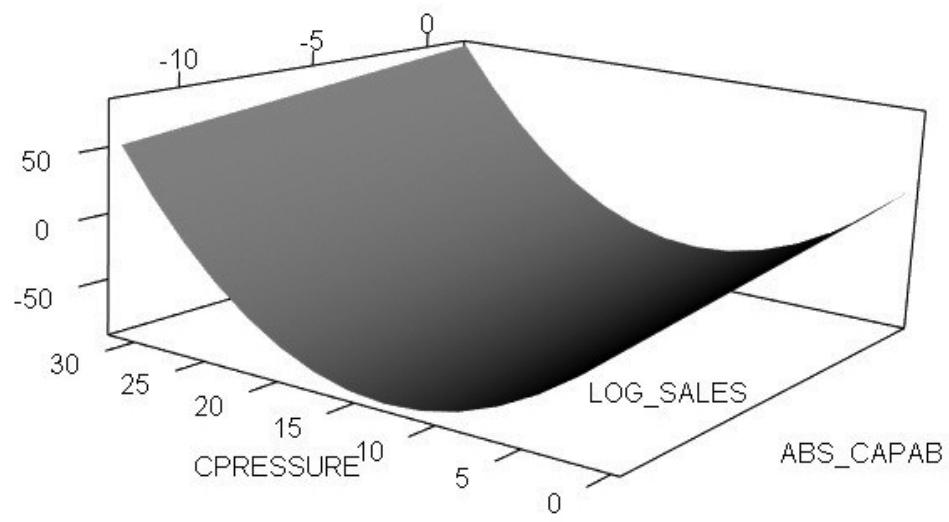

Figure 1. Graphical representation of results from Model 1

Note: The figure delineates the predicted values of sales (in logs) given competitive pressure, absorptive capacity, and their interaction at different variable values (holding the rest of the variables at their mean). One can deduce that strong absorptive capacity is more conducive for smaller firms (scoring high on the competitive pressure variable) rather than for larger firms. This is further buttressed when considering exclusively the largest firms with zero competitive pressure value (see the descriptive statistics in Table 2), as their interaction effect takes on zero values, as well. 
ers the proposed effect by Hypothesis 3: technologically advanced products deteriorate the volume of sales. Hypothesis 3 is also demonstrated by Model 2 when a U-shaped effect is revealed with regard to the rate of the technological content of the product portfolio and the participation in technology alliancing. In contrast to the proposed effects postulated by Hypothesis 3, Model 3 demonstrates an inverted U-shape effect between the technological content of the product portfolio and firm performance, which highlights that Hypothesis 3, being associated with the rate of product portfolio innovativeness, has the least relevance with patenting activity as a performance indicator. Accordingly, the technological content of the product portfolio positively influences the practices of patenting at its lower values, and this effect becomes negative at higher variable values. As a possible explanation, there may be an attention problem of trained personnel in choosing higher rates of product development vis-á-vis patent crafting processes. The curvilinear relationships between the technological degree of the product portfolio and the indicators of firm performance in Models 2 and 3 are graphically depicted

Table 5

Results of Model 2

\begin{tabular}{|c|c|c|c|}
\hline \multirow{3}{*}{$\begin{array}{l}\text { Method } \\
\text { Dependent variable }\end{array}$} & \multicolumn{2}{|c|}{ Logit Model } & \\
\hline & \multicolumn{2}{|c|}{ TECHN_ALLIANCING } & \\
\hline & \multicolumn{2}{|c|}{ Model 2} & \\
\hline & Coefficient & Std error & \\
\hline Constant & -0.45 & 0.32 & \\
\hline \multicolumn{4}{|l|}{ Core variables } \\
\hline CPRESSURE & 0.01 & 0.03 & \\
\hline CPRESSURE X ABS_CAPAB & 0.01 & 0.03 & \\
\hline TECH_PP & -0.03 & 0.01 & $* * *$ \\
\hline TECH_PP2 & 0.0002 & 0.0001 & $* * *$ \\
\hline \multicolumn{4}{|l|}{ Control variables } \\
\hline ABS_CAPAB & -0.13 & 0.05 & $* *$ \\
\hline GEO_MARK & 0.08 & 0.07 & \\
\hline INVESTMENT_DA & 0.06 & 0.10 & \\
\hline TURBULENCE & 0.020 & 0.01 & \\
\hline IND_PARK & 0.56 & 0.27 & * \\
\hline ABS_SIZE & -0.05 & 0.04 & \\
\hline Goodman and Kruskal's lambda & 0.66 & & \\
\hline Hosmer and Lemeshow test & \multicolumn{2}{|c|}{$\mathrm{p}$-value $=0.26$} & \\
\hline
\end{tabular}

Note: $* * * p$-value $<0.001, * * p$-value $<0.01, * p$-value $<0.05$. 
by Figures 2 and 3, respectively. Regarding these figures, one can observe that the slope shift in Figure 2 (Figure 3) is located at 64 (56) on the minimum (maximum) value of the curve, well between the actual variable range. For instance, using data from Table 2, the sum of the mean and one standard deviation value of TECH_PP is equal to 71.49, which shows the abundance of observations beyond the inflection point, facilitating the quadratic term to set in.

As far as it concerns our control variables, the estimates of the GEO_MARK variable report that firms with an international market orientation tend to enjoy enhanced performance in sales (Model 1) and patent granting (Model 3). As an additional check, we redid the analysis considering GEO_MARK as a pure qualitative variable. Ultimately, the results (available upon request from the authors) of the core and control variables remained unchanged. Coefficient estimates for absorptive capacity prove negative and significant in all models, which suggest that when considered alone, absorptive capacity has no intrinsic value but incurs heavy development costs, thus lowering performance.

The turbulent nature of the environment appears to be insignificant in all models. Investments in downstream activities contribute to patenting performance through better commercialisation opportunities shown by Model 3, but contrary to expectations, it deteriorates the amount of sales (Model 1). Collocation in industrial parks is conducive to networking via better access to knowledgeable alliance partners and exerts no effect on patent crafting. Its effect is negative and marginally significant only in the case of firm sales that might be attributed to knowledge dissipation from proximate rivals situated in the same cluster, which leads to a negative spillover balance (Jaffe et al. 1993; Alcácer - Chung 2007). Not surprisingly, firm size positively influences performance implied by all indicators of performance, except technological networking (Model 2) where the variable does not reach established levels of significance. Finally, the goodnessof-fit measures in Model 1 clearly demonstrate that it is properly adjusted to the data set. In the logistic regressions displayed by Models 2 and 3, we include the Goodman-Kruskal's lambda and the Hosmer-Lemeshow test. According to these tests, our Models 2 and 3 are properly adjusted to the data, as well.

\section{CONCLUSIONS}

We investigated empirically the determinants of firm performance across a range of dimensions critical to success. To this end, we distinguished three dimensions: sales volume, participation in technology alliancing, and successful patent issuing. We obtained our data from the 2006 and 2008 PITEC database, which is the Spanish equivalent of the EU Community Innovation Survey. Our findings suggest that 


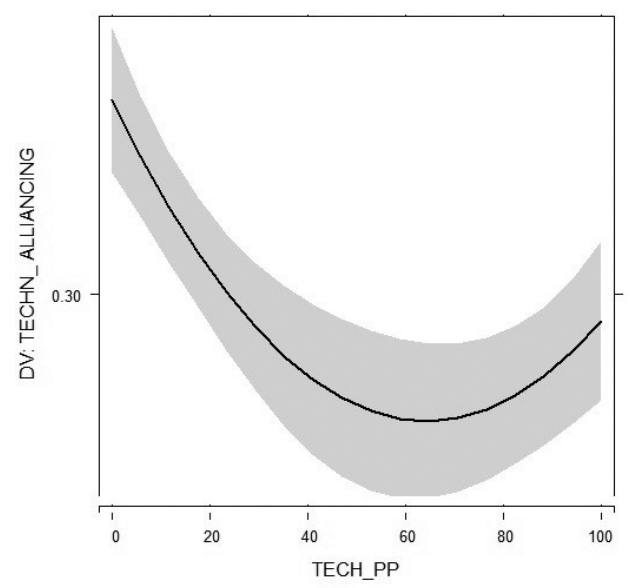

Figure 2. Curvilinear relationship from Model 2

Note: The horizontal axis delineates the values of the technological degree of the product portfolio (TECH_PP) that can vary between 0 (minimum value) and 100 (maximum value), while the vertical corresponds to the probability of establishing a strategic technology alliance. The figure demonstrates the U-shaped effect between the predictor and the performance variable. The dark area visualizes the confidence interval of 95 percent.

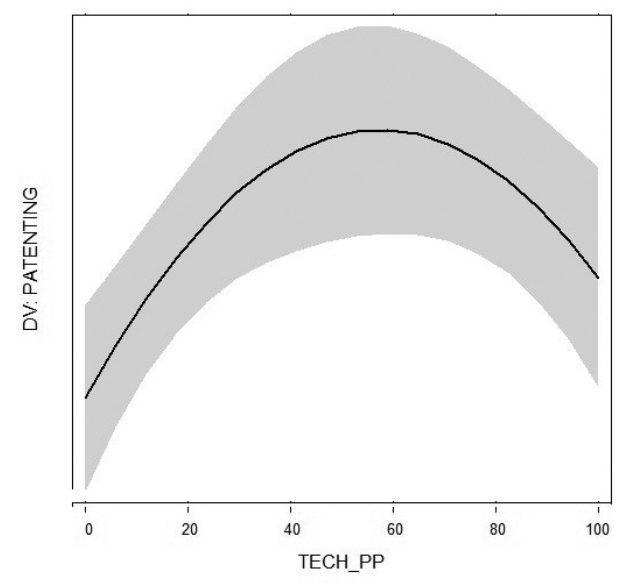

Figure 3. Curvilinear relationship from Model 3

Note: The horizontal axis delineates the values of the technological degree of the product portfolio (TECH_PP) that can vary between 0 (minimum value) and 100 (maximum value), while the vertical corresponds to the probability of issuing a patent. The figure demonstrates the inverted U-shaped effect between the predictor and the performance variable. The dark area visualizes the confidence interval of 95 percent. 
Table 6

Results of Model 3

\begin{tabular}{|c|c|c|c|}
\hline \multirow{3}{*}{$\begin{array}{l}\text { Method } \\
\text { Dependent variable }\end{array}$} & \multicolumn{2}{|c|}{ Logit Model } & \\
\hline & \multicolumn{2}{|c|}{ PATENTING } & \\
\hline & \multicolumn{2}{|c|}{ Model 3} & \\
\hline & Coefficient & Std error & \\
\hline Constant & -3.64 & 0.34 & $* * *$ \\
\hline \multicolumn{4}{|l|}{ Core variables } \\
\hline CPRESSURE & 0.05 & 0.03 & \\
\hline CPRESSURE X ABS_CAPAB & -0.01 & 0.03 & \\
\hline TECH_PP & 0.02 & 0.01 & $* * *$ \\
\hline TECH_PP ${ }^{2}$ & -0.0002 & 0.0001 & $* *$ \\
\hline \multicolumn{4}{|l|}{ Control variables } \\
\hline ABS_CAPAB & -0.27 & 0.05 & $* * *$ \\
\hline GEO_MARK & 0.28 & 0.07 & $* * *$ \\
\hline INVESTMENT_DA & 0.20 & 0.10 & $*$ \\
\hline TURBULENCE & -0.003 & 0.01 & \\
\hline IND_PARK & 0.35 & 0.25 & \\
\hline ABS_SIZE & 0.17 & 0.04 & $* * *$ \\
\hline Goodman and Kruskal's lambda & 0.77 & & \\
\hline Hosmer and Lemeshow test & \multicolumn{2}{|c|}{$\mathrm{p}$-value $=0.48$} & \\
\hline
\end{tabular}

Note: ${ }^{* *} p$-value $<0.001$, ** $p$-value $<0.01$, * $p$-value $<0.05$.

competitive pressure (aggregate distance from larger rivals in an industry), the possession of absorptive capacity, and a product portfolio of high levels of technological content are important factors in explaining firm performance. However, their effects are dependent on the adopted type of performance measure.

Accordingly, higher rates of competitive pressure only affect smaller firms in their sales levels, but not other performance dimensions. Such a negative effect might be reverted with stronger absorptive capacity. The technological degree of the product portfolio is a key factor in determining firm performance. To elicit more precise links with firm performance, we aimed to grasp potential curvilinearity. Results are mixed. Technologically advanced products reduce sales volume. Relatedly, there exists a U-shaped effect with the technological degree of the product portfolio and the participation in technology alliancing. On the other hand, we explored an inverted U-shaped relation that product characteristics exhibit with patenting.

We also showed that firms with a higher international scope clearly favour company sales and patenting. Absorptive capacity, as a stand-alone strategy, proves extremely costly to organisations, causing performance deterioration. The 
turbulent nature of the environment does not hinder firm performance in any of the specifications. Downstream activities to capture a more advantageous market presence promote patenting, but, surprisingly, hinder sales. Being situated in an industrial park fosters patenting, but adversely affects sales performance. Furthermore, except for technology alliancing, the estimates of the absolute size variable enhance sales and patenting performance.

Complementing prior studies, we detected some specific organisational and within-industrial traits that had not been studied before. Our research implies a theoretical value addition for the body of literature addressing the study of firm performance. Furthermore, practitioners also benefit in the sense that they can tailor more appropriately their growth strategies by taking into consideration the highlighted organisational attributes. Our study is not exempt of limitations. One of them is the application of a more detailed data set through which more finegrained performance measures could be applied. As an example, one could explore the value of patents and the range of patent classes to which the firm is able to actively contribute. Furthermore, the extent of success in technology alliances could be better modelled by considering marketable products as outcomes of the process or by the amount of transferred technological knowledge from partners.

\section{REFERENCES}

Alcácer, J. - Chung, W. (2007): Location Strategies and Knowledge Spillovers. Management Science, 53(5): 760-776.

Almirall, E. - Casadeus-Masanell, R. (2010): Open versus Closed Innovation: A Model of Discovery and Divergence. Academy of Management Review, 35(1): 27-47.

Anderson, P. - Tushman, M.L. (1990): Technological Discontinuities and Dominant Designs: A Cyclical Model of Technological Change. Administrative Science Quarterly, 35: 604-633.

Ansoff, H.I. - Stewart, J.M. (1967): Strategies for a Technology-Based Business. Harvard Business Review, 45(6): 71-83.

Arbussá, A. - Coenders, G. (2007): Innovation Activities, Use of Appropriation Instruments and Absorptive Capacity: Evidence from Spanish Firms. Research Policy, 36(10): 1545-1558.

Barge-Gil, A. (2010): Open, Semi-Open and Closed Innovators: Towards an Explanation of Degree of Openness. Industry and Innovation, 17(6): 577-607.

Barnett, W.P. - Sorenson, O. (2002): The Red Queen in Organizational Creation and Development. Industrial and Corporate Change, 11(2): 289-325.

Barroso, A. - Giarratana, M.S. (2013): Product Proliferation Strategies and Firm Performance: The Moderating Role of Product Space Complexity. Strategic Management Journal, 34(12): 1435-1452.

Baum, J.A.C. - Silverman, B.S. (2004): Picking Winners or Building Them? Alliance, Intellectual, and Human Capital as Selection Criteria in Venture Financing and Performance of Biotechnology Start-ups. Journal of Business Venturing, 19(3): 411-436. 
Carroll, G.R. - Swaminathan, A. (2000): Why the Microbrewery Movement? Organizational Dynamics of Resource Partitioning in the US Brewing Industry. American Journal of Sociology, 106(3): 715-762.

Chiaroni, D. - Chiesa, V. - Frattini, F. (2011): The Open Innovation Journey: How Firms Dynamically Implement the Emerging Innovation Management Paradigm. Technovation, 31(1): 34-43.

Cohen, W. - Levinthal, D. (1989): Innovation and Learning: The Two Faces of R\&D. Economic Journal, 99: 569-596.

Cohen, W. - Levinthal, D. (1990): Absorptive Capacity: A New Perspective on Learning and Innovation. Administrative Science Quarterly, 35(1): 128-152.

Dobrev, S. - Carroll, G.R. (2003): Size (and Competition) among Organizations: Modelling ScaleBased Selection among Automobile Producers in Four Major Countries, 1885-1981. Strategic Management Journal, 24(6): 541-558.

Dobrev, S. - Kim, T.Y. - Carroll, G.R. (2002): The Evolution of Organizational Niches: U.S. Automobile Manufacturers, 1885-1981. Administrative Science Quarterly, 47(2): 233-264.

Dobson, A.J. (2002): An Introduction to Generalized Linear Models. New York: Chapman \& Hall.

Eggers, J.P. (2012): All Experience is not Created Equal: Learning, Adapting, and Focusing in Product Portfolio Management. Strategic Management Journal, 33(3): 315-335.

Escribano, A. - Fosfuri, A. - Tribo, J.A. (2009): Managing External Knowledge Flows: The Moderating Role of Absorptive Capacity. Research Policy, 38(1): 96-105.

Fabrizio, K.R. (2009): Absorptive Capacity and the Search for Innovation. Research Policy, 38(2): 255-267.

Folta, T.B. - Cooper, A.C. - Baik, Y.S. (2006): Geographic Cluster and Firm Performance. Journal of Business Venturing, 21(2): 217-242.

Gans, J.S. - Stern, S. (2003): The Product Market and the Market for “Ideas”: Commercialization Strategies for Technology Entrepreneurs. Research Policy, 32(2): 333-350.

Garud, R. - Kumaraswamy, A. (1993): Changing Competitive Dynamics in Network Industries: An Exploration of Sun Microsystems Open Systems Strategy. Strategic Management Journal, 14(5): 351-369.

Giarratana, M.S. (2004): The Birth of a New Industry: Entry by Start-ups and the Drivers of Firm Growth: The Case of Encryption Software. Research Policy, 33(5): 787-806.

Giarratana, M.S. - Fosfuri, A. (2007): Product Strategies and Survival in Schumpeterian Environments: Evidence from the US Security Software Industry. Organization Studies, 28(6): 909929.

Goodman, L.A. - Kruskal, W.H. (1954): Measures of Association for Cross Classifications. Journal of the American Statistical Association, 49: 732-764.

Greene, W.H. (2008): Econometric Analysis. New Jersey: Prentice Hall.

Helfat, C.E. (1997): Know-How and Asset Complementarity and Dynamic Capability Accumulation: The Case of R\&D. Strategic Management Journal, 18(5): 339-360.

Henderson, R. - Cockburn, I. (1996): Scale, Scope, and Spillovers: The Determinants of Research Productivity in Drug Discovery. RAND Journal of Economics, 27(1): 32-59.

Hosmer, D.W. - Lemeshow, S. (1989): Applied Logistic Regression. New York: Wiley.

Jaffe, A. - Trajtenberg, M. - Henderson, R. (1993): Geographic Localization of Knowledge Spillovers as Evidenced by Patent Citations. Quarterly Journal of Economics, 108(3): 577-598.

Jones, G.R. - Hill, C.W.L. (1988): Transaction Cost Analysis of Strategy-Structure Choice. Strategic Management Journal, 9(2): 159-172.

Kim, D.J. - Kogut, B. (1996): Technological Platforms and Diversification. Organization Science, 17(3): 283-301. 
Klepper, S. - Simons, K.L. (2000): Dominance by Birthright: Entry of Prior Radio Producers and Competitive Ramification in the U.S. Television Receiver Industry. Strategic Management Journal, 21(10-11): 997-1016.

Lancaster, K.M. (1990): The Economics of Product Variety. Marketing Science, 9(3): 189-211.

Laursen, K. - Salter, A. (2006): Open for Innovation: The Role of Openness in Explaining Innovation Performance among U.K. Manufacturing Firms. Strategic Management Journal, 27(2): 131-150.

Lee, S. - Park, G. - Yoon, B. - Park, J. (2010): Open Innovation in SMEs - An Intermediated Network Model. Research Policy, 39(2): 290-300.

Nelson, R.R. - Winter, S. (1982): An Evolutionary Theory of Economic Change. Cambridge, MA: Harvard University Press.

Sakkab, N.Y. (2002): Connect - Develop Complements Research - Develop at P-G. ResearchTechnology Management, 45(8): 38-45.

Santamaría, L. - Nieto, M.J. - Barge-Gil, A. (2009): Beyond Formal R\&D: Taking Advantage of Other Sources of Innovation in Low- and Medium-Technology Industries. Research Policy, 38(3): 507-517.

Schmalensee, R. (1978): Entry Deterrence in the Ready-to-Eat Breakfast Cereal Industry. Bell Journal of Economics, 9(2): 305-327.

Sorenson, O. (2000): Letting the Market Work for You: An Evolutionary Perspective on Product Strategy. Strategic Management Journal, 21(5): 577-592.

Teece, D.J. (1986): Profiting from Technological Innovation: Implications for Integration, Collaboration, Licensing, and Public Policy. Research Policy, 15(6): 285-305.

The Economist (2011a): The Next Big Bet. 1 October 2011.

The Economist (2011b): Economies of Scale Made Steel. 12 November 2011.

van den Bosch, F.A.J. - Volberda, H.W. - de Boer, M. (1999): Co-Evolution of Firm Absorptive Capacity and Knowledge Environment: Organizational Forms and Combinative Capabilities. Organization Science, 10(5): 551-568.

Zahra, S.A. - George, G. (2002): Absorptive Capacity: A Review, Re-Conceptualization, and Extension. Academy of Management Review, 27(2): 185-203. 